Citation: Sosnowski, W. P., \& Tymoshuk, R. (2017). On The dictionary of active Polish and Ukrainian phraseology [Leksykon aktywnej frazeologii polskiej i ukraińskiej]. Contrastive linguistics and culture. Cognitive Studies / Études cognitives, 2017(17). https://doi.org/10.11649/ cs. 1317

\author{
WOJCIECH PAWE€ SOSNOWSKI ${ }^{1, A}$ \& ROMAN TYMOSHUK ${ }^{2, B}$ \\ ${ }^{1}$ Institute of Slavic Studies, Polish Academy of Sciences, Warsaw, Poland \\ 2 Ukrainian Lingua-Information Fund, National Academy of Sciences of Ukraine, Kiev, Ukraine \\ $A_{\text {wpsosnow@uw.edu.pl ; }}{ }^{B}$ roman.tymoshuk@gmail.com
}

\title{
ON THE DICTIONARY OF ACTIVE POLISH AND UKRAINIAN PHRASEOLOGY [LEKSYKON AKTYWNEJ FRAZEOLOGII POLSKIEJ I UKRAIŃSKIEJ]. CONTRASTIVE LINGUISTICS AND CULTURE
}

\begin{abstract}
The Dictionary of Active Polish and Ukrainian Phraseology [Leksykon aktywnej frazeologii polskiej i ukraińskiej] is the first publication of its kind in the history of Polish and Ukrainian lexicography. It consists of equivalent phrasal units in Polish and Ukrainian. The innovative aspect of the lexicon is that it uses a semantic metalanguage to establish equivalent units. The authors developed a new method of searching for equivalent units which uses the meaning not the form - as the starting point. This method enables the identification of equivalent units in both languages. Moreover, it enables the identification of units that do not have equivalents. The units which lack equivalents are usually deeply rooted in Poland's or Ukraine's historical and cultural context, and are thus defined as culturemes. Even though they lack equivalents, it was decided not to exclude them from the Leksykon's structure, as they are actively used by the speakers of Polish and Ukrainian. This paper provides an overview of the Leksykon's methodology and presents the authors' definition of phraseologism. The most important points in the paper are illustrated with a number of example entries from the dictionary. The primary focus of the paper rests on phrasal units which lack equivalents.

Keywords: phraseologism; cross-linguistic equivalence; phrasal dictionary; semantic metalanguage; phraseography; linguistic worldview; cultureme
\end{abstract}

\section{Introduction}

Leksykon aktywnej frazeologii polskiej i ukraińskiej [The Dictionary of Active Polish and Ukrainian Phraseology] — edited by Tymoshuk, Sosnowski, Jaskot and Ganoshenko — is a ground-breaking 
publication in the history of Polish and Ukrainian lexicography. To date, no bilingual dictionary of Polish and Ukrainian phraseology has been published. The dictionary is a response to the processes taking place in the 21st century - globalization, the European Union, and the flourishing cooperation between Poland and Ukraine. It promotes multilingualism and helps lay the foundations for better bilateral relations between Poland and Ukraine

The dictionary is aimed at native Polish and Ukrainian readers, as well as all speakers of Polish and Ukrainian around the world: Slavicists, lexicographers, encyclopaedia writers, students, etc. The dictionary contains over 1,000 of the most frequent phrasal units in contemporary Ukrainian and Polish. The dictionary was created using a universal semantic metalanguage, which allows for the potential addition of an unlimited number of languages (including non-Slavic languages). The addition of new languages is also made easier by the new methodology developed by the dictionary's authors, i.e. descriptive equivalents. Due to its innovative methodology, the dictionary can serve as the basis for new contemporary multilingual dictionaries, in particular phraseological dictionaries and dictionaries of idioms. One of the dictionary's most important features is the fact that it contains not only general phraseology, but also new phrasal coinages (phrasal neologisms) and active phrasal culturemes. Culturemes cannot usually attain full equivalence, because they are a reflection of a given nation's culture and its linguistic worldview.

\section{Contemporary Polish and Ukrainian lexicography}

Contrastive studies in Polish and Ukrainian phraseology are a fairly recent development in Slavic linguistics. Over the last two decades, there has been a surge in the number of studies on Slavic phraseology, especially on its linguistic and cultural aspects. Nevertheless, Ukrainian and Polish phraseologies have been lagging behind. There are hardly any books or papers contrasting the two.

Without a doubt, Luchyk, Antonova \& Dubrovs'ka's (Лучик, Антонова, \& Дубровська, 2011) and Luchyk \& Antonova's (Лучик \& Антонова, 2013) dictionaries should be regarded as the two great achievements of Polish-Ukrainian lexicography. Both dictionaries consist of a special type of language unit: units which are situated between phraseologisms, idioms and lexemes, e.g.

- DO NIEPOZNANIA ksiaż. analog przystówka (w sposób uniemożliwiający lub bardzo utrudniający poznanie, nie do poznania) до невпізнання (непізнання) [невпізнанності]

- В (У) ХОДу́ в ролі присудка (у вжитку, в обігу) w obiegu, w użyciu

The language units in the dictionaries are the equivalents of adverbs, nouns, adjectives, conjunctions, exclamations and other fixed phrases. These units consist of different parts of speech, but cannot be classified as any part of speech themselves. They play an important role in everyday communication. These units not only carry semantic meaning, but also - more importantly pragmatic meanings, whose construction is different in every language and every national discourse (Космеда, Осіпова, \& Піддубна, 2015, p. 45). Phrasal information was also covered in Levchenko's (Левченко, 2011) and Kononenko \& Spivak's (Кононенко \& Співак, 2008) dictionaries. The former contains a study on similes, whereas the latter is on Ukrainian-Polish language interference.

\section{The definition of a phraseological unit in the dictionary}

In order to select the phraseological units for the dictionary, it was necessary to establish a workable definition of a phraseologism. The decades of work by the scholars in ULIF NANU on contrastive 
phraseology in Polish and Ukrainian laid the theoretical foundations for the dictionary. ${ }^{1}$

The initial assumption was that a phraseologism is an irreducible and stable semantic unit, used to convey a holistic meaning, which cannot be arrived at as a simple sum of its parts. The defining feature of a phraseological unit is its complex semantics, which arises from the linguistic worldview of a given nation. The key issue which needed solving during the work on the dictionary was the choice of adequate equivalents, which would take into account the differences in the worldviews of the two nations (Tymoshuk, Vilchynska, Shyrokov, \& Nadutenko, 2015, p. 320).

Phraseological units can only be defined by taking their semantics as the point of departure. This is due to the fact that phraseologisms develop independently in every language. Therefore, the compilation of the dictionary started with semantics. To achieve this, a semantic metalanguage was used as the basis for the interpretation of phraseological units in both languages. Most researchers studying the relation between lexemes and phraseological units have highlighted the semantic and functional correlations between the two. There is no agreement yet on the place of phraseology in language systems. Arkhangel'skiǐ (Архангельский, 1972, pp. 182-188), for instance, sees lexemes and phraseologisms as two different types of units engaging in hierarchical relations. At the same time, Arkhangel'skir situates both types of units at the same level in the language hierarchy, defining them as the "building blocks" of sentences. The semantic structure of phraseological units has so far engendered the biggest controversy. Kunin (Кунин, 1996) singled out two different types of meanings: a phraseological meaning and a lexical meaning. The reason for this separation was that the semantic structure of a phraseologism and that of a lexeme are not identical: "the complexity of phraseological semantics derives from the special nature of the phraseological meaning. That special nature has its roots in many different phenomena: a phraseologism consists of at least two different lexemes and its [syntactic] structure can be highly complex - ranging from single-component phrases to multiclausal sentences" (Кунин, 1996, pp. 134-136).

Drawing a clear boundary between a phraseologism and a non-phraseologism is a complicated task. In contrastive linguistics, it is very difficult to decide whether a unit is a phraseologism or not - one never knows whether to use criteria typical for one language or the other. Each national tradition in linguistics takes a different approach to the issue of phraseologisms. ${ }^{2}$ How are the following types of phraseologisms classified?

- Collocations - are sometimes categorised as phraseologisms (e.g. brać udział / бpamu участь, odnieść zwycięstwo / здобути перемогу)

- Fixed phrases - usually seen as the core part of a dictionary; they allow a slight desemanticisation of one component (wilczy apetyt / вовчий anemum, gęsia skórka / гусяча uкipa)

- Word-equivalent units (e.g. pod adresem / в адpecy)

- Specialist collocations (teoria informacji / теорія інформаціï) (Tymoshuk et al., 2015, p. 320)

Having analysed the data, it was decided to include in the dictionary:

(a) fixed phrases whose meanings are not a sum of the meanings of the expression's components: Pol. szara eminencja, gra niewarta świeczki, zbijać bąki, ciężki kawatek chleba, grubymi nićmi szyty; Ukr. години пік, вибити з колї, дивитися крізь рожеві окуляри, корона з голови не впаде, пилинки здувати;

(b) fixed phrases in which one of the components' semantics has attenuated (or desemanticised): Pol. wilczy głód, grobowa cisza, głowa rodziny, lwia część, Ukr. голлівудсъка посмішка, відмивати гроші, коронна страва, повний абзач;

(c) formulaic similes: Pol. czuć się jak ryba w wodzie, głupi jak but, idzie jak burza, potrzebny

\footnotetext{
${ }^{1}$ ULIF NANU (Український мовно-інформаційний фонд НАН України) specialise in mathematical, applied and computational linguistics. ULIF NANU develop state-of-the-art methodologies in linguistics and ensure the efficient functioning of Ukrainian (and other languages) in digital communication systems.

${ }^{2}$ For more information see Corpas Pastor (2016).
} 
jak dziura w mоście; Ukr. прачювати як кінъ, дурний як валянок, спати як немовля, змерзнути як иуцик.

\section{Active phraseologisms}

Dictionaries traditionally include examples of use extracted from fictional literature. Using examples derived from corpora is quite problematic - the experience of building multilingual corpora for CLARIN-PL (n.d.) attests to that (cf. Sosnowski, 2016, pp. 339-349). The data analysed (over 6 million lexemes) only very rarely contained contexts where there was a phraseological unit in each of the compared languages. An example of such a context is shown below:

[Pl] Nigdy nie wyznałem swej $\mid[\mathrm{Bg}]$ „Не се признах в любов“|[Ru] Я «не позволял своmiłości słowami, ale jeżeli oczy гласно; и все пак, ако очите ей любви высказаться вслух»; mają wymowę, to każda gąska могат да говорят, дори един однако, если взгляды могут musiałaby odgadnąć, że byłem идиот би могъл да долови, че говорить, и круглый дурак zakochany po uszy. съм влюбен до уши. догадался бы, что я по уши влюблен.

Wells, H. G. War of the Worlds (source: Korpus równoległy polsko-bułgarsko-rosyjski Clarin-PL)

The most common situation was where a phraseological unit was present in only one of the languages:

[Pl] To ludzie bez ducha, bez $\mid[\mathrm{Bg}]$ Те нямат дух, те не зна- $\mid[\mathrm{Ru}]$ У них нет мужества, нет dumnych snów, bez wzniosłych ят какво е горди мечти и гор- гордости, они не умеют сильporywów. A człowiek bez tego ди въжделения, а всеки, кой- но желать. А без этого челоto zwykły tchórz, to szmata. $\quad$ то не познава нито едното, ни- век гроша ломаного не стото другото - боже мой! - та $u m$.

той е пълен със страхове и опасения!

Bronte, E. Wuthering Heights (źródło: Korpus równoległy polsko-bułgarsko-rosyjski Clarin-PL)

\subsection{What is an active phraseologism?}

The dictionary contains over 1000 phraseological units from Polish and Ukrainian (500 each). An active phraseologism is a phraseologism frequently used by native speakers in the spoken and / or written variety of the language and understood by other native speakers (i.e. another native speaker would be able to convey a similar meaning using different words). The dictionary also includes a group of phraseologisms found as a result of an analysis of mass media discourse and online communication.

\subsection{Selecting phraseologisms}

The data collection involved a number of stages: (1) Native speakers of Polish and Ukrainian, aged between 15 and 45, were interviewed. (2) Online communication (text messages, posts and notifications on Facebook) were analysed. (3) Active phraseologisms were extracted from advertising, press articles, contemporary pop songs and dialogues in contemporary films and TV series. The obtained data was subsequently analysed by two linguists from Poland and two linguists from Ukraine. At the next stage, pre-selected phraseologisms were cross-validated against phraseological dictionaries (Sobol \& Bralczyk, 2008; Kłosińska, Sobol, \& Stankiewicz, 2014; Білоноженко, Гнатюк, Дятчук et al., 2008) and other monolingual dictionaries. Finally, a questionnaire was conducted in order to narrow down the selection. Some phraseologisms have multiple acceptable 
variants in dictionaries, e.g. odwracać / wykręcać / wywracać kota ogonem. The respondents were asked to choose the one which they would most likely use. As a result, the phraseologism was included only in its most "popular" version: odwracać kota ogonem. This procedure was applied to a number of other phraseologisms. It was decided to omit the so-called international phraseologisms, e.g. Pol. miecz Damoklesa, pięta Achillesowa, manna z nieba; Ukr. дамоклів меч, перейти рубікон, троянсъкий кінъ. The only exception to this decision were international phraseological units that were actively used by respondents.

\subsection{Selecting examples of use}

Since using corpus examples was either difficult or impossible, it was decided to create original examples or use sentences which had previously been heard in conversation. Efforts were taken to ensure that each and every example clearly demonstrates how a given phraseologism works in everyday Polish and Ukrainian usage.

\section{Semantic metalanguage}

If one assumes that a phraseological unit behaves similarly to a word, one can use a universal semantic metalanguage to compare and contrast two or more languages. This method was previously used in Leksykon odpowiedniości semantycznych $w$ języku polskim, bułgarskim i rosyjskim (edited by W. Sosnowski, V. Koseska-Toszewa and A. Kisiel) (Sosnowski, Koseska-Toszewa, \& Kisiel, 2016). An example is given below:

\begin{tabular}{|c|c|c|}
\hline $\begin{array}{l}\text { блин I, -á } r z . m . l . m n . \\
\text { блинь́ } \\
\text { 'cienki placek z rzadkiego ciasta } \\
\text { usmażony na patelni' } \\
\text { печъ блины }\end{array}$ & $\begin{array}{l}\text { блини́ (pl. tantum) } \\
\text { 'cienki placek z rzadkiego } \\
\text { ciasta usmażony na patelni' } \\
\text { Тук серви́рат блини́. }\end{array}$ & $\begin{array}{l}\text { blin, -a; -y rz. mniézyw. } \\
\text { 'cienki placek z rzadkiego ciasta } \\
\text { usmażony na patelni' } \\
\text { nasmażyć blinów }\end{array}$ \\
\hline $\begin{array}{l}\text { блин II part. żarg. } \\
\text { 'używane przy wyrażaniu zdzi- } \\
\text { wienia, zmartwienia, irytacji, } \\
\text { niezadowolenia (uważane za } \\
\text { eufemistyczne)' } \\
\text { Блин, как я могла́ ему́ пове́- } \\
\text { ритъ! } \\
\text { Блин, вот э́то маши́на! }\end{array}$ & $\begin{array}{l}\text { дя́вол да го взе́ме! } \\
\text { wykrzyknik, żarg. } \\
\text { 'używane przy wyrażaniu zdzi- } \\
\text { wienia, zmartwienia, irytacji, } \\
\text { niezadowolenia (uważane za } \\
\text { eufemistyczne)' } \\
\text { Пак ме излб́гаха, дя́вол да го } \\
\text { вз́́ме! }\end{array}$ & $\begin{array}{l}\text { kurczę wykrzyknik } \\
\text { 'używane przy wyrażaniu zdzi- } \\
\text { wienia, zmartwienia, irytacji, } \\
\text { niezadowolenia (uważane za } \\
\text { eufemistyczne)' } \\
\text { Kurcze jak mogtam w to uwie- } \\
\text { rzyć! } \\
\text { O kurcze, ale samochód! }\end{array}$ \\
\hline
\end{tabular}

Leksykon odpowiedniości semantycznych w języku polskim, bułgarskim i rosyjskim (W. Sosnowski; V. Koseska-Toszewa; A. Kisiel)

\subsection{Unit definitions in the dictionary}

An attempt was made to write the definitions in the dictionary using as simple words as possible. Defining units with their synonyms was avoided whenever possible - full definitions were chosen instead. Each meaning of a given unit is illustrated with a different sample sentence. The sample sentences also demonstrate the grammatical properties of units, e.g. the valency of a verb, rection, or the typical word order for units which require it. The definitions in the dictionary were constructed in accordance with the following models: 
'o kimś, kto' ('about someone / someone')

być $\mathrm{w}$ siódmym niebie

'wtedy, gdy ktoś jest bardzo zadowolony z czegoś'

Jestem w siódmym niebie, gdy odpoczywam na plażach Morza Azowskiego.

'o czymś, co' ('about something / something')

grubymi nićmi szyty

'o czymś, co jest nieumiejętnie zamaskowane'

Jego zeznania sa grubymi nićmi szyte. Ciekawe,

czy sad sie na nie nabierze... бу́ти на сьо́мому не́бі

'тоді, коли хтось дуже задоволений чимось'

Наречена була на съомому небі від щастя.

'o kimś (czymś), kto (co)' ('about somebody or something that')

na wagę złota

'o kimś (czymś), kto (co) ma wielką wartość'

Wskazówki mojego promotora okazaty się na wage ztota.

\section{бі́лими нитка́ми ши́тий}

'про щось, що погано, невміло замасковано'

Ця легенда білими нитками шита.

'o takim (...), który' ('about $x$, which')

ciężki kawałek chleba

'o takiej pracy lub zawodzie, które są trudne i o takich środkach materialnych, które sa zdobywane z trudem'

Praca nauczyiela to cięzki kawatek chleba, ale przynosi też sporo satysfakcji. на вагу́ зо́лота

'про когось (щось), хто (що) має велику цінність'

Кожна його порада на вагу золота.

\section{тяжки́й хліб}

'про таку роботу або професію, яка є складною, або про матеріальні засоби, що здобуваються важко'

Робота в школі для молодой вчительки виявилася тяжким хлібом.

'wtedy, gdy' ('when')

диви́тися крізь роже́ві окуля́ри

'тоді, коли хтось не помічає недоліків у комусь (чомусь)'

Ï̈ часто називали мрійливою дивачкою, адже вона дивилася на світ крізъ рожеві окуляри. patrzeć (na coś) / widzieć (coś) przez różowe okulary

'wtedy, gdy ktoś nie zauważa wad w kimś (czymśs)'

Po wyjeździe za granice od razu Ola zaczęta patrzeć przez różowe okulary, bo skończyly sie problemy finansowe.

\section{Contrastive linguistics and multilingual equivalents}

The definition of equivalence used in the research derives from the contemporary semantics and contrastive linguistics theories developed in Gramatyka konfrontatywna bułgarsko-polska (Koseska-Toszewa \& Gargov, 1990; Koseska-Toszewa, 2006; Koseska-Toszewa, Korytkowska, \& Roszko, 2007). This was the first comparative grammar created using a semantic metalanguage. This method differs from traditional contrastive linguistics, which stipulates that the comparison of two (or more) languages depends crucially on the primary language. This traditional method can often lead to the development of inaccurate or entirely false descriptions. In the metalanguage 
method, the process of contrasting two (or more) languages proceeds from a meaning to its expression. The traditional method, in contrast, would begin with an expression in one language and proceed to an equivalent expression in the other language. Thanks to the metalanguage method, different languages can be treated as equals in descriptions. The decision to begin with semantics enables the dictionary to capture the differences and similarities in the meaning of phraseological units in both Polish and Ukrainian.

\section{Culturemes and the question of equivalence}

There are two types of equivalence in the dictionary: translational equivalence and systemic equivalence (cf. Dobrovolski, 2011). The dictionary includes a number of translational equivalents, which are the equivalents of a given phraseological unit in the other language. In accordance with Dobrovolski's (2011) typology, there are four types of equivalents in the dictionary:

(a) full equivalents (Pol. kropla w morzu (potrzeb) — Ukr. кpanля в морi; Pol. królik doświadczalny - Ukr. піддослідний кролик; Pol. głodny jak wilk - Ukr. голодний як вовк),

(b) partial equivalents (Pol. dać w tapę - Ukr. damu на лany; Pol. palce lizać - Ukr. nальчикu оближеш),

(c) parallel equivalents (Pol. być dobrej myśli — Ukr. не naдатu dyxoм; Pol. czuć (do kogoś) mięte (przez rumianek) - Ukr. нерівно дихати),

(d) zero equivalents (Pol. czeski bład - Ukr. descriptive equivalent: друкарсъка помилка, описка; Pol. sto lat za Murzynami - Ukr. descriptive equivalent: відсталий, малорозвинений).

Groups (c) and (d) contain phraseological units which are typical of a given nation's culture. They are not usually idiomatic in the other language and would not be understood by its speakers. Below are several more examples:

\section{czeski film}

'wtedy, gdy nie wiadomo, o co chodzi' Wasze opowieści z urlopu to jakiś czeski film! descriptive equivalent: щось невідо́ме, незрозумі́ле; ка́зна-що́

'тоді, коли невідомо, про що йдеться'

The above expression (czeski film, lit. 'a Czech film') came to existence in the 1970s after the Polish premiere of the Czech film Nikdo nic nevi ('Nobody Knows Anything'). Polish TV showed many Czech films and series in the 1970s. Their plots were usually too convoluted and slow-paced for the average Polish viewer.

\section{krakowskim targiem}

'wtedy, gdy ktoś dochodzi do kompromisu' Chciatem sprzedać samochód za dwadzieścia tysięcy, kupiec byt gotów dać dziesięć. Krakowskim targiem sprzedatem wreszcie za piętnaście tysięcy.

\section{ні на́шим ні ва́шим}

'тоді, коли хтось іде на компроміс'

Давайте ні нашим ні вашим - за три тислиі!

Krakowskim targiem (lit. 'by a Cracovian haggle') derives from the fact that Poles perceive people from Cracow and Lesser Poland as misers who would haggle no matter what until they get the price they want. This expression contains a crucial onomastic component (Cracow), just like the Ukrainian example below: 
пройти́ Крим і Рим ${ }^{3}(\mathbf{i}$ мі́дні тру́би)

'тоді, коли, хтось пройшов різні випробування і набув великого досвіду'

У нашій команді з'явилися досвідчені гравиі, які пройшли Крим і Рим. jeść chleb z niejednego pieca

'wtedy, gdy ktoś wszędzie był, wiele przeżył i doświadczył'

Chtopak Basi jadt chleb $z$ niejednego pieca. Podobno pracowat téz jako marynarz $i$ byt nawet w Australii.

The Ukrainian expression балувана Галя has its roots in a Ukrainian anecdote popular in the 1990s. Over time, the anecdote got "compressed" to one short expression. In Polish, this expression has a formal equivalent: francuski piesek (lit. 'a French dog'). The two expressions are a good example of a parallel equivalent:

\section{ба́лувана Га́ля}

'про когось, хто перебірливий, примхливий' Вадим - че балувана Галя. Під час відпочинку вибирав тільки п'ятизіркові готелі.

\section{francuski piesek}

'o kimś, kto jest kapryśny i wybredny'

Marek to francuski piesek $i$ na pewno nie pojedzie z nami w Bieszczady.

Contrasting Polish and Ukrainian data led to the discovery of units which did not have formal equivalents. These were mostly phrasemes containing a significant amount of knowledge specific to a given culture: czeski film, krakowskim targiem Ukr. пройmu Крим і Рим, балувана Галя (see above), as well as narobić bigosu, rozebrać się jak do rosołu Ukr. заварити кашу, як вареник / cup y маслi. They belong to the category of culturemes. ${ }^{4}$ They are included in the dictionary because they are particularly common in contemporary spoken Polish and Ukrainian. The dictionary's approach to culturemes is in line with that of Jaskot \& Ganoshenko, who find that "the approaches to culturemes developed to date do not take into account all the relevant aspects of language, disregarding the inherent asymmetry of meaning and its manifestation. The semantic 'load' of a cultureme is much higher than that of a concept rooted in reality, because culturemes convey meaning related to cultural information, then extrapolated onto other levels of cultural worldview" (Jaskot \& Ganoshenko, 2015, p. 116). As a result of many centuries of shared customs and traditions, the cultural worldviews and philosophies of Poland and Ukraine do not differ greatly. However, one can still find discrepancies between the two. Let us analyse the following examples taken from the dictionary:

narobić bigosu kol.

'wtedy, gdy ktoś narobił zamieszania i sprawił komuś kłopot'

Ostatnimi zeznaniami narobit bigosu $i$ sprawe odroczono do czerwca.

\section{як варе́ник / сир у ма́слі}

'тоді, коли хтось живе дуже добре, безтурботно, в достатку'

Молодий бізнесмен почав займатися нерухомістю і тепер живе як вареник у маслі.

\section{завари́ти ка́шу}

'тоді, коли хтось затіяв щось складне, клопітне, завдав комусь турбот'

Я ию кашу заварив, мені й відповідати за все.

\section{jak pączek w maśle}

'wtedy, gdy komuś żyje się bardzo dobrze, beztrosko i w dostatku'

Od kiedy zaczat prace w szwajcarskiej firmie, ma sie jak paczek w maśle.

The four examples above contain some core phraseological components that constitute nonequivalent lexemes. Native speakers of Polish and Ukrainian do not perceive these components as deeply embedded in their national cultures, because they have undergone full lexicalisation. Nevertheless, each of the above phraseologisms is motivated by a cultural concept characteristic of the given nation:

\footnotetext{
${ }^{3}$ Por. pol. Gdzie Rzym, (a) gdzie Krym (lit. 'Where Rome, where Crimea').

${ }^{4}$ According to Nord, a cultureme is a "social phenomenon of a culture $\mathrm{X}$ that is regarded as relevant by the members of this culture and, when compared with a corresponding social phenomenon in a culture $\mathrm{Y}$, is found to be specific to culture X" (1997, p. 204).
} 
- bigos is "a Polish dish of finely chopped meat of various kinds stewed with sauerkraut and shredded fresh cabbage", 5

- paczek is a "a small, round, fried cake, sometimes with a hole in the middle", ${ }^{6}$ essentially a doughnut; doughnuts are known in many other European cultures, but they are of great cultural significance in Poland, because people eat them in large quantities on Fat Thursday, ${ }^{7}$

- вареники are "filled dumplings of East European origin ... made by wrapping pockets of unleavened dough around a savory or sweet filling and cooking them in boiling water"; 8 they are one of the national dishes of Ukraine,

- kaua "is a dish made of any kind of grains boiled in water or milk ... [t] he word generally refers to roasted whole-grain buckwheat or buckwheat groats"; ${ }^{9}$ it is typical for both Polish and Ukrainian culinary traditions; Ruthenians used to cook гуртової kasha - a ritual dish consumed during religious feasts, whose preparation and consumption was a symbol of being part of the society.

In the above examples, one can see that a cultureme in one language is substituted by a cultureme typical for the other language, e.g. narobic bigosu ('make mess / cause problems', lit. 'make bigos') $\rightarrow$ заварити кашу (lit. 'cook kasha'). As far as the language systems are concerned, the substitution does not affect the equivalence between the languages. According to Jaskot \& Ganoshenko, "the key task in translating pragmatics in lexicography is to [allow a reader to fully understand] the linguistic sign, which will transcend the ethnolinguistic barriers, based on the asymmetry of ethnomental culturemes. This entails that a lexicographer must overcome the issue of differences in linguistic worldviews and non-equivalent lexis" (Jaskot, \& Ganoshenko, 2015, p. 118).

Words accumulate experience - they have a form of semantic memory. Therefore, only by being a reflection of people's experience and cultural traditions can they become a linguistic sign that is comprehensible to native speakers: "languages aggregate and transmit from generation to generation phraseologisms which, directly or indirectly, refer to norms, stereotypes and myths which form part of material and immaterial national cultures" (Онкович, 1997, p. 34). It is not possible to get a clear picture of the linguistic worldview and the cultural mindset of a given nation, unless one studies the cultural components of phraseologisms.

When contrasting languages, one often comes across ethnonyms, i.e. names of ethnic communities: nations, families or tribes. These names reflect the attitudes communities hold towards other communities. Many phraseologisms in the dictionary contain ethnonyms. In Polish, these were (among others): siedzieć jak na tureckim kazaniu [lit. 'like sitting at a Turkish sermon'] 'a situation in which one is listening to something that one does not understand', udawać Greka [lit. 'pretend to be Greek'] 'a situation when one pretends one does not know anything about a given issue', wolna amerykanka [lit. 'free American'; no-rules wrestling] 'a type of behaviour when one does not observe any rules', sto lat za Murzynami [lit. 'one hundred years behind the Negroes'] 'about something that is backwards and underdeveloped'. In Ukrainian, you can come across such ethnonyms as: китаєць 'Chinese person' (китайсъка грамота [lit. 'Chinese charter'] 'something incomprehensible', китайсъкі церемонї [lit. 'Chinese ceremonies'] 'about superfluous social norms'), турок 'a Turkish person' (сидіти як турок [lit. 'sit like a Turk'] 'a situation when one is listening to something that one does not understand'), нiмець 'a German person' (як німець [lit. 'like a German'] 'a situation when someone remains silent'), циган 'a Romani person' (крутити як ииган сонцем [lit. 'rotate like a gypsy rotates the sun'] 'a situation when someone is bossy or manipulative'). The phrase wyjść po angielsku Ukr. піти по-англійсъжи [lit. 'take an English leave] is an internationalism ${ }^{10}$ used both in Polish and Ukrainian.

\footnotetext{
${ }^{5}$ https://en.wikipedia.org/wiki/Bigos

${ }^{6}$ http://dictionary.cambridge.org/dictionary/english-polish/doughnut

${ }^{7}$ An equivalent of English Shrove Tuesday.

${ }^{8}$ https://en.wikipedia.org/wiki/Pierogi

${ }^{9}$ https://en.wikipedia.org/wiki/Kasha

${ }^{10}$ Cf. Spa. 'salir a la francesa', Por. 'sail a francesa', Eng. 'take French leave', Ger. 'Einen Polnischen machen'.
} 
As far as non-equivalent lexis is concerned, an interdisciplinary consensus has been reached: the semantic concepts in a given language are specific to this language, hence, they are at least partially unique. Consequently, the lexical semantic structures of two (or more) languages are not isomorphic. The lack of isomorphism between languages has sparked multiple theoretical and empirical studies of non-equivalence in many fields of inquiry. As far as the present study is concerned, the focus rests only on the metalexicographic aspect of the issue. We are of the opinion that studies in lexicographic non-equivalence should not be based on counterintuitive definitions that depart from the meaning of non-equivalence in natural languages. That said, a more precise definition of non-equivalence is still required, a definition that would incorporate the findings of other branches of linguistics, esp. contrastive linguistics and translation theory (Jaskot \& Ganoshenko, 2015, pp. 118-119).

When studying the equivalence of phraseologisms between languages, one needs to distinguish between the cultural meaning and the source of linguistic and cultural information. One needs to find the motivation for the phraseologism, which usually derives from a combination of social, cultural, historical, religious and mythological factors. Once the motivations for phraseologisms are established, their national and cultural characteristics can be better understood.

\section{Homonymy between languages}

Contrasting phraseologies of different languages is an activity with many pitfalls. For instance, there are phrases whose forms are apparently identical, but whose meanings differ, e.g. Pol. idzie jak krew z nosa (= painfully slow), Ukr. кров з носа (= immediately), Pol. ostrzyć zęby (= expect that one will obtain something one wants), Ukr. гострити зуби (= want to hurt sb), Pol. postawić na nogi (= motivate sb to take action), Ukr. поставити на ноги (= raise sb), Pol. owinać sobie wokót palca kogoś (= subdue sb), Ukr. обвести навколо пальия (= cunningly lie to sb).

Because Polish and Ukrainian are so closely related, translators experience difficulties when translating phrases or words that have a similar form but different meanings, i.e. interlanguage homonyms or false friends (Шмелев, 2008; Хуцишвили, 2010; Jaskot, 2013). Studies of Polish and Ukrainian phraseology have shown that the semantic structure of phraseologisms in these two languages can differ significantly. This is a result of the differences between the two cultures and the way they are reflected in phraseologisms.

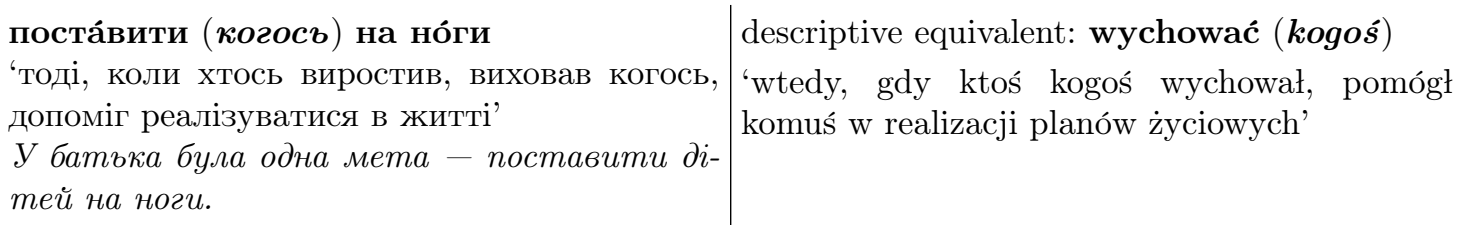

The above example shows that the Ukrainian phrase поставити (когосъ) на ноги means 'raise sb', whereas the similar Polish phrase postawić (coś or kogoś) na nogi means something completely different (i.e. 'motivate sb to take action').

We can see similar diffences between the Ukrainian тримати (когосъ) на короткому повідку and the Polish owinać / owijać sobie (kogoś) wokót palca:

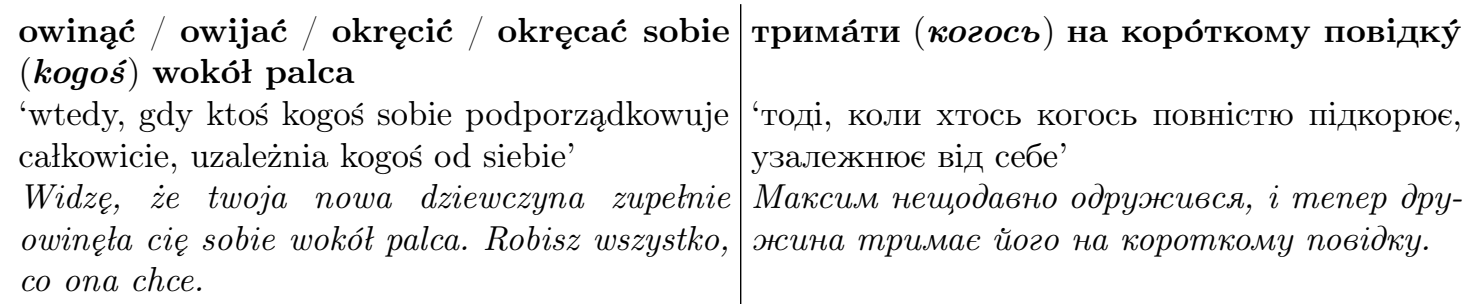


обвести́ (когосъ) навко́ло па́льця

'тоді, коли хтось когось обманює, дурить'

I як це тільки тобі вдаеться? Знову обвів викладача навколо пальия і склав іспит на 'відмінно'. wystawić / wystawiać (kogoś) do wiatru 'wtedy, gdy ktoś oszukuje kogoś, zawodzi go' Jeśli jeszcze raz mnie wystawisz do wiatru, to możemy sie pożegnać.

Phenomena such as the above examples should be analysed in every study which investigates the phraseological equivalence between languages. Moreover, they need to be taken into consideration when including phraseological units in dictionaries.

\section{Conclusions}

By comparing the Polish and the Ukrainian phraseological data, it was possible to have a close examination of the phraseological units that are deeply embedded in national cultures - both Ukrainian and Polish. These units are classified as culturemes, because their meaning derives directly from the cultures and histories of Poland and Ukraine. It was decided not to exclude these units from the dictionary, because they are actively used in contemporary spoken Polish and Ukrainian. The methodology employed had been developed based on numerous studies on interlanguage equivalence, false friends, interlanguage homonymy, and linguistic worldview. A semantic metalanguage was developed, which was subsequently used for the presentation of the phraseological units in the lexicon. The methodology - being a compromise between the Ukrainian and Polish traditions in linguistics - gave very satisfying results and enabled the creation of an innovative dictionary. In the future, the dictionary can be used as the basis for new contemporary phraseological dictionaries, and motivate linguists to create new resources and tools, such as multilingual electronic dictionaries.

\section{References}

CLARIN-PL. (n.d.). Retrieved from https://clarin-pl.eu/pl/category/clarin-pl/

Corpas Pastor, G. (Ed.). (2016). Computerised and corpus-based approaches to phraseology: Monolingual and multilingual perspectives [Fraseología computacional y basada en corpus: Perspectivas monolingües y multilingües]. Geneva, Switzerland: Tradulex. Retrieved 2 April 2016, from http://www.tradulex. com/varia/Europhras2015.pdf

Dobrovolski, D. (2011). Cross-linguistic equivalence of idioms: Does it really exist? In A. Pamies \& D. Dobrovolski (Eds.), Linguo-cultural competence and phraseological motivation (pp. 7-24). Baltmannsweiler: Schneider Verlag.

Jaskot, M. (2013). Los asi llamados falsos amigos del traductor entre el español y el Esperanto (Rozprawa doktorska obroniona w Uniwersytecie Warszawskim 3.09.2013 r., w posiadaniu autora).

Jaskot, M., \& Ganoshenko, J. (2015). Culturemes and non-equivalent lexis in dictionaries. Cognitive Studies / Études cognitives, 2015(15), 115-124. https://doi.org/10.11649/cs.2015.009

Kisiel, A., Satoła-Staśkowiak, J., \& Sosnowski, W. (2014a). The need for an electronic multilingual dictionary. Cognitive Studies / Études cognitives, 2014(14), 55-64. https://doi.org/10.11649/cs. 2014. 006

Kisiel, A., Satoła-Staśkowiak, J., \& Sosnowski, W. (2014b). Прикладна лінгвістика та лінгвістичні технологіï, MegaLing-2013: Зб. наук. np. (рр. 112-120). Київ: Національна академія наук України, Український мовно-інформаційний фонд.

Kłosińska, A., Sobol, E., \& Stankiewicz, A. (2014). Wielki słownik frazeologiczny PWN z przysłowiami. Warszawa: Wydawnictwo Naukowe PWN.

Koseska-Toszewa, V. (2006). Gramatyka konfrontatywna butgarsko-polska (Vol. 7, Semantyczna kategoria czasu). Warszawa: Instytut Slawistyki Polskiej Akademii Nauk.

Koseska-Toszewa, V., Korytkowska, M., \& Roszko, R. (2007). Polsko-butgarska gramatyka konfrontatywna. Warszawa: Wydawnictwo Akademickie Dialog. 
Koseska-Toszewa, V., \& Sosnowski, W. (2015). Multilingualism and dictionaries. Cognitive Studies / Études cognitives, 2015(15), 43-55. https://doi.org/10.11649/cs.2015.004

Nord, C. (1997). Translating as a purposeful activity. Manchester: St. Jerome Publishing.

Satoła-Staśkowiak, J. (2016). Żart w procesie neologizacji — na podstawie języka młodego pokolenia. Językoznawstwo, 2016(10), 185-192.

Sobol, E., \& Bralczyk, J. (2008). Słownik frazeologiczny PWN: Z Bralczykiem. Warszawa: Wydawnictwo Naukowe PWN.

Sosnowski, W. (2016). The parallel Polish-Bulgarian-Russian corpus: Problems and solutions. In G. Corpas Pastor (Ed.), Computerised and corpus-based approaches to phraseology: Monolingual and multilingual perspectives [Fraseología computacional y basada en corpus: Perspectivas monolingües y multilingües] (pp. 396-406). Geneva, Switzerland: Tradulex.

Sosnowski, W., Koseska-Toszewa, V., \& Kisiel, A. (Eds.). (2016). Leksykon odpowiedniości semantycznych w języku polskim, bułgarskim i rosyjskim (Vol. 1). Warszawa: Instytut Slawistyki Polskiej Akademii Nauk.

Tymoshuk, R., Vilchynska, K., Shyrokov, V., \& Nadutenko, M. (2015). Semantic interpretation of phraseological units in Ukrainian-Polish electronic phraseological dictionary. Cognitive Studies / Études cognitives, 2015(15), 319-325. https://doi.org/10.11649/cs.2015.021

Tymoszuk, R., Sosnowski, W., Jaskot, M., \& Ganoszenko, J. (2017). Leksykon aktywnej frazeologii polskiej i ukraińskiej. Warszawa: KJV Digital.

Архангельский, В. Л. (1972). О задачах, объектах и разделах русской фразеологии как лингвистической дисциплины. In Проблемы устойчивости и вариантности фразеологических единиц: Материаль межвузовского симпозиума (Vol. 2, pp. 182-188). Тула.

Білоноженко, В. М., Гнатюк, I. С., Дятчук, В. В. et al. (2008). Словник фразеологізмів українсъкоӥ мови. Київ: Наукова думка.

Кононенко, І., \& Співак, О. (2008). Украӥнсъко-полъсъкий словник міжсмовних омонімів $і$ паронімів. Київ: Вища школа.

Косеска-Тошева, В, \& Гаргов, Г. (1990). Българско-полска съпоставителна граматика (Vol. 2, Cемантичната категория определеност/неопределено ). София: БАН.

Космеда, Т. А., Осіпова, Т. Ф., \& Піддубна, В. В. (2015). Українсько-польські та польсько-українські словники усталених виразів: проблемні питання. Лінгвістичні дослідження: Збірник наукових працъ Харківсъкого начіоналъного педагогічного університету ім. Г. С. Сковороди, 2015(39), 43-55. https://doi.org/10.5281/zenodo.18927

Кунин, А. В. (1996). Курс фразеологии современного английского языка (2nd еd.). Москва: Высшая школа.

Левченко, О. (2011). Українсъко-російсъко-білорусъко-болгарсъко-полъсъкий словник порівнянъ. Львів: Львівська політехніка.

Лучик, А., Антонова, О., \& Дубровська, I. (2011). Украӥнсъко-польсъкий словник еквівалентів слова. Київ: Український мовно-інформаційний фонд НАН України, Національний університет «КиєвоМогилянська академія», Інститут славістики Польської академії наук.

Лучик, А., \& Антонова, О. (2013). Полъсъко-украӥнсъкий словник еквівалентів слова. Київ: Український мовно-інформаційний фонд НАН України, Національний університет «Києво-Могилянська академія», Інститут славістики Польської академії наук.

Онкович, Г. В. (1997). Украӥнознавство і лінгводидактика: Навч. Посібник. Київ: Логос.

Тимошук, Р. П. (2016). Семантична інтерпретація фразеологічних одиниць в українсько-польській двомовній лексикографії. In Прикладна лінгвістика та лінгвістичні технологї (pp. 75-82). Київ.

Тимошук, Р. П., Вільчинська, Х. П., \& Широков, В. А. (2014). Принципи укладання українськопольського електронного фразеологічного словника. In Прикладна лінгвістика та лінгвістичні технологї (рp. 211-219). Київ.

Український національний лінгвістичний корпус. (n.d.). Retrieved from http://unlc.icybcluster. org.ua/virt_unlc/

Хуцишвили, С. (2010). Славянские межъязыковые омонимы (Doctoral dissertation). Тбилиси. Retrieved 2 April 2016, from http://old.press.tsu.ge/GEO/internet/disertaciebi/S. Khutsishvili\%20Disertacia.pdf

Широков, В. А. (Наук. керівник). (n.d.). Словник українсъкої мови: У $20 \mathrm{~m}$. Retrieved from http: //lcorp.ulif.org.ua/vll/ 
Широков, В. А., Шевченко, І. В., Рабулець, О. Г. et al. (2009). Словники Украӥни - інтегрована лексикографічна система: Парадигма. Транскрипція. Фразеологія. Синонімія. Антонімія. Електронний ресурс. Версія 4.1. Retrieved from http://lcorp.ulif.org.ua/dictua/

Шмелев, Д. Н. (2008). Проблемъ семантического анализа лексики. Санкт-Петербург: ЛКИ.

\section{References (Transliteration)}

Arkhangel'skiǐ, V. L. (1972). O zadachakh, ob"ektakh i razdelakh russkoǐ frazeologii kak lingvisticheskoǐ distsipliny. In Problemy ustořchivosti $i$ variantnosti frazeologicheskikh edinits: Materialy mezhvuzovskogo simpoziuma (Vol. 2, pp. 182-188). Tula.

Bilonozhenko, V. M., Hnatiuk, I. S., Diatchuk V. V. et al. (2008). Slovnyk frazeolohizmiv ukraïns'koï movy. Kyïv: Naukova dumka.

CLARIN-PL. (n.d.). Retrieved from https://clarin-pl.eu/pl/category/clarin-pl/

Corpas Pastor, G. (Ed.). (2016). Computerised and corpus-based approaches to phraseology: Monolingual and multilingual perspectives [Fraseología computacional y basada en corpus: Perspectivas monolingües y multilingües]. Geneva, Switzerland: Tradulex. Retrieved 2 April 2016, from http://www.tradulex. com/varia/Europhras2015.pdf

Dobrovolski, D. (2011). Cross-linguistic equivalence of idioms: Does it really exist? In A. Pamies \& D. Dobrovolski (Eds.), Linguo-cultural competence and phraseological motivation (pp. 7-24). Baltmannsweiler: Schneider Verlag.

Jaskot, M. (2013). Los asi llamados falsos amigos del traductor entre el español y el Esperanto (Rozprawa doktorska obroniona w Uniwersytecie Warszawskim 3.09.2013 r., w posiadaniu autora).

Jaskot, M., \& Ganoshenko, J. (2015). Culturemes and non-equivalent lexis in dictionaries. Cognitive Studies / Études cognitives, 2015(15), 115-124. https://doi.org/10.11649/cs.2015.009

Khutsishvili, S. (2010). Slavianskiie mezh"iazykovyie omonimy (Doctoral dissertation). Tbilisi. Retrieved 2 April 2016, from http://old.press.tsu.ge/GEO/internet/disertaciebi/S.Khutsishvili\% 20Disertacia.pdf

Kisiel, A., Satoła-Staśkowiak, J., \& Sosnowski, W. (2014a). The need for an electronic multilingual dictionary. Cognitive Studies / Études cognitives, 2014(14), 55-64. https://doi.org/10.11649/cs.2014. 006

Kisiel, A., Satoła-Staśkowiak, J., \& Sosnowski, W. (2014b). O rabote nad mnogoiazychnym slovarem. In Prykladna linhvistyka ta linhvistychni tekhnolohï, MegaLing-2013: Zb. nauk. pr. (pp. 112-120). Kyïv: Natsional'na akademiia nauk Ukraïny, Ukraïns'kyı̆ movno-informatsiŭnyı̆ fond.

Kłosińska, A., Sobol, E., \& Stankiewicz, A. (2014). Wielki słownik frazeologiczny PWN z przysłowiami. Warszawa: Wydawnictwo Naukowe PWN.

Kononenko, I. \& Spivak, O. (2008). Ukraïns'ko-pol's'kyı̆ slovnyk mizhmovnych omonimiv $i$ paronimiv. Kyïv: Vyshcha shkola.

Koseska-Tosheva, V., \& Gargov, G. (1990). Bŭlgarsko-polska sŭpostavitelna gramatika (Vol. 2, Semantichnata kategoriia opredelenost/neopredelenost). Sofiia: BAN.

Koseska-Toszewa, V. (2006). Gramatyka konfrontatywna bułgarsko-polska (Vol. 7, Semantyczna kategoria czasu). Warszawa: Instytut Slawistyki Polskiej Akademii Nauk.

Koseska-Toszewa, V., \& Sosnowski, W. (2015). Multilingualism and dictionaries. Cognitive Studies / Études cognitives, 2015(15), 43-55. https://doi.org/10.11649/cs.2015.004

Koseska-Toszewa, V., Korytkowska, M., \& Roszko, R. (2007). Polsko-bułgarska gramatyka konfrontatywna. Warszawa: Wydawnictwo Akademickie Dialog.

Kosmeda, T. A., Osipova, T. F., \& Piddubna, V. V. (2015). Ukraïns'ko-pol's'ki ta pol's'ko-ukraïns'ki slovnyky ustalenykh vyraziv: problemni pytannia. Linhvistychni doslidzhennia: Zbirnyk naukovykh prats' Kharkivs'koho natsional'noho pedahohichnoho universytetu im. H. S. Skovorody, 2015(39), 43-55. https://doi.org/10.5281/zenodo.18927

Kunin, A. V. (1996). Kurs frazeologii sovremennogo angliǔskogo iazyka (2nd ed.). Moskva: Vysshaia shkola.

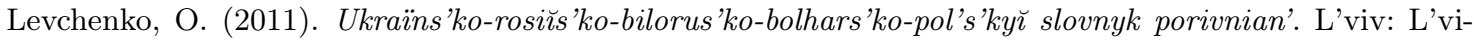
vs'ka politekhnika.

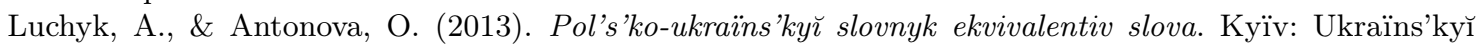
movno-informatsiı̆nyı̆ fond NAN Ukraïny, Natsional'nyı̆ universytet «Kyievo-Mohylians'ka akademiia», Instytut slavistyky Pol's'koï akademiï nauk. 
Luchyk, A., Antonova, O., \& Dubrovs'ka, I. (2011). Ukraïns'ko-pol's'ky̆ slovnyk ekvivalentiv slova. Kyïv: Ukraïns'kyı̆ movno-informatsiǔnyı̌ fond NAN Ukraïny, Natsional'nyı̌ universytet «Kyievo-Mohylians'ka akademiia», Instytut slavistyky Pol's'koï akademiï nauk.

Nord, C. (1997). Translating as a purposeful activity. Manchester: St. Jerome Publishing.

Onkovych, H. V. (1997). Ukraïnoznavstvo i linhvodydaktyka: Navch. Posibnyk. Kyïv: Lohos.

Satoła-Staśkowiak, J. (2016). Żart w procesie neologizacji — na podstawie języka młodego pokolenia. Językoznawstwo, 2016(10), 185-192.

Shmelev, D. N. (2008). Problemy semanticheskogo analiza leksiki. Sankt-Peterburg: LKI.

Shyrokov, V. A. (Ed.). (n.d.). Slovnyk ukraïns'koï movy: U 20 t. Retrieved from http://lcorp.ulif .org. $\mathrm{ua} / \mathrm{vll} /$

Shyrokov, V. A., Shevchenko, I. V., Rabulets', O. H. et al. (2009). Slovnyky Ukrä̈ny — intehrovana leksykohrafichna systema: Paradyhma. Transkryptsiia. Frazeolohiia. Synonimiia. Antonimiia. Versiia 4.1. Retrieved from http://lcorp.ulif.org.ua/dictua/

Sobol, E., \& Bralczyk, J. (2008). Słownik frazeologiczny PWN: Z Bralczykiem. Warszawa: Wydawnictwo Naukowe PWN.

Sosnowski, W. (2016). The parallel Polish-Bulgarian-Russian corpus: Problems and solutions. In G. Corpas Pastor (Ed.), Computerised and corpus-based approaches to phraseology: Monolingual and multilingual perspectives [Fraseología computacional y basada en corpus: Perspectivas monolingües y multilingües] (pp. 396-406). Geneva, Switzerland: Tradulex.

Sosnowski, W., Koseska-Toszewa, V., \& Kisiel, A. (Eds.). (2016). Leksykon odpowiedniości semantycznych w języku polskim, bułgarskim i rosyjskim (Vol. 1). Warszawa: Instytut Slawistyki Polskiej Akademii Nauk.

Tymoshuk, R. P. (2016). Semantychna interpretatsiia frazeolohichnykh odynyts' v ukraïns'ko-pol's'kiı̌ dvomovniı̌ leksykohrafiï. In Prykladna linhvistyka ta linhvistychni tekhnolohï (pp. 75-82). Kyïv.

Tymoshuk, R. P., Vil'chyns'ka, K. P., \& Shyrokov, V. A. (2014). Pryntsypy ukladannia ukraïns'kopol's'koho elektronnoho frazeolohichnoho slovnyka. In Prykladna linhvistyka ta linhvistychni tekhnolohï (pp. 211-219). Kyïv.

Tymoshuk, R., Vilchynska, K., Shyrokov, V., \& Nadutenko, M. (2015). Semantic interpretation of phraseological units in Ukrainian-Polish electronic phraseological dictionary. Cognitive Studies / Études cognitives, 2015(15), 319-325. https://doi.org/10.11649/cs.2015.021

Tymoszuk, R., Sosnowski, W., Jaskot, M., \& Ganoszenko, J. (2017). Leksykon aktywnej frazeologii polskiej i ukraińskiej. Warszawa: KJV Digital.

Ukraïns'kyı̌ natsional'nyı̌ linhvistychnyı̆ korpus. (n.d.). Retrieved from http://lcorp.ulif .org.ua/virt_ unlc/

\section{Acknowledgment}

This work was financed by the Polish Ministry of Science and Higher Education and a core funding for statutory activities from the Ministry of Education and Science of Ukraine.

The authors declare that they have no competing interests.

The authors' contribution was as follows: concept of the study: Wojciech Paweł Sosnowski; data analyses: Wojciech Paweł Sosnowski and Roman Tymoshuk; the writing: Wojciech Paweł Sosnowski and Roman Tymoshuk.

This is an Open Access article distributed under the terms of the Creative Commons Attribution 3.0 PL License (http://creativecommons.org/licenses/by/3.0/pl/), which permits redistribution, commercial and noncommercial, provided that the article is properly cited.

(C) The Authors 2017

Publisher: Institute of Slavic Studies, Polish Academy of Sciences, University of Silesia \& The Slavic Foundation 